\title{
Perilaku Ibu Yang Berhubungan Dengan Kejadian Diare Pada Balita
}

\author{
${ }^{1}$ Revi Meliani, ${ }^{2}$ Lisneni Dewi* \\ STIKESMAS Abdi Nusa Palembang \\ *email : lisneni@yahoo.com
}

Kata Kunci:

Perilaku Ibu

(Pemberian ASI,

Penggunaan

Botol susu dan

Kebiasaan

mencuci

tangan), keajdian

diare.

Keywords:

Mother's

behavior; (breast

feeding, Using

milk bottles and

hand washing

habits), diarrhea.

Info Artikel:

Info Artikel:

Tanggal dikirim:

7 Juli 2019

Tanggal direvisi:

23 Juli 2019

Tanggal diterima:

25 Juli 2019

DOI Artikel:

10.33862/citradel

ima.v3i1.63

Halaman: 31-36

\section{Abstrak}

Diare merupakan penyebab kematian terbesar ke dua pada Balita di Dunia setelah penyakit Pneumonia. Diare adalah suau keadaan peradangan pada mukosa lambung dan usus halus yang mengakibatkan pengekuaran feases yang tidak normal dan tidak seperti biasanya dengan konsistensi lembek atau cair, bahkan dapat juga berupa air saja dengan frekuensi yang lebih sering dari biasanya (3 kali atau lebih) dalam satu hari. Berdasarkan laporan Tahun 2015 sampai Tahun 2017 Puskesmas Kenten Kota Palembang penderita diare pada balita masih sangat tinggi, dan pada Tahun 2018 dari bulan Januari sampai dengan Mei terdapat 150 penderita diare balita. Penelitian ini bertujuan untuk mengetahui faktorfaktor perilaku ibu yang berhubungan dengan kejadian diare pada balita. Jenis penelitian ini adalah deskriptif analitik yaitu penelitian yang menggali bagaimana fenomena kesehatan terjadi dengan pendekatan cross sectional dimana variabel independen dan variabel dependen di observasi sekaligus pada saat yang sama. Populasi penelitian adalah seluruh ibu yang memiliki balita yang diare dan sampel yang diambil berjumlah 60 orang. Tehnik pengambilan sampel dilaksanakan dengan cara accidental sampling. Faktor-faktor perilaku ibu yang diukur meliputi, pemberian ASI, cara penggunaan botol susu dan kebiasaan mencuci tangan. Data dianalisis dengan chi-square. Hasil penelitian menunjukkan bahwa dari kejadian diare pada balita dengan diare berat sebesar 53.3\% dan dengan diare ringan sebesar 46,7\%. Hasil analisis bivariat menunjukkan bahwa ketiga faktor perilaku ibu ada hubungan dengan kejadian diare pada balita pada variabel pemberian ASI didapatkan $\mathrm{PR}=2,731$, penggunaan botol susu didapatkan $\mathrm{PR}=2,551$ dan kebiasaan mencuci tangan $\mathrm{PR}=1,737$.

\section{Abstract}

Diarrhea is the second largest cause of death for children in the world after pneumonia. Diarrhea is a condition of mucosal inflammation of the stomach and small intestine resulting in abnormal and unusualness expenditure with a soft or liquid consistency; even it can be in the form of water with higher frequency than usual( 3 times or more) in a day. Based on reports of Puskesmas Kenten Palembang City from 2015 to 2017, children with diarrhea were still very high, and from January to May 2018, there were 150 children with diarrhea. This study aims to determine maternal behavioral factors associated with the incidence of diarrhea in children. This is descriptive analytical research, research that explores how health phenomena occur with a cross-sectional approach where the independent variables and dependent variables are observed at the same time. The population is all mothers who have children with diarrhea, and the samples are 60 people. The sampling technique is accidental sampling. Factors of maternal behavior measured include breastfeeding, how to use milk bottles and hand washing habits. Data are analyzed by chi-square. The results show that the incidence of diarrhea in children with severe diarrhea is $53.3 \%$ and with mild diarrhea of $46.7 \%$. The results of the bivariate analysis show that all three factors of maternal behavior correlate with the incidence of diarrhea in children on breast feeding variables obtained $P R=2.731$, using milk bottles obtained $P R=2.551$ and handwashing habits obtained $\mathrm{PR}=1.737$.

\section{PENDAHULUAN}

Diare merupakan penyebab kematian terbesar kedua pada balita di dunia setelah penyakit pneumonia. Menurut data dari United Nations Children's Fund (UNICEF) dan WHO, hmapir sekitar satu dari lima kematian anak balita di dunia disebabkan karen diare. Angka kematian balita yang disebabkan karena diare mencapai 1,5 juta http://jurnalilmiah.stikescitradelima.ac.id/index.php/JI Vol.3,No.1, Juli 2019

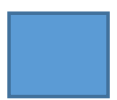


per tahun. Insiden terbesarnya terjadi pada 2 tahun pertama kehidupan dan menurun seiring dengan pertumbuhan anak.

Peyakit diare masih menjadi masalah global dengan derajat kesakitan dan kematian yang tinggi di berbagai negara terutama di negara berkembang, dan juga sebagai salah satu penyebab utama tingginya angka kesakitan dan kematian anak di dunia. Secara umum diperkirakan lebih dari 10 juta anak berusia kurang dari 5 tahun meninggal setiap tahunnya di dunia dimana sekitar $20 \%$ meninggal karena infeksi diare. (Sodikin, 2011)

Dari hasil survey morbiditas yang dilakukan oleh Departemen Kesehatan, pada tahun 2012 angka kesakian diare pada balita 900 per 1.000 balita, tahun 2013 insiden diare pada balita sebesar 6,7\%. Tahun 2015 terjadi 18 kali Kejadian Luar Biasa diare dengan jumlah penderita 1.213 orang dan kematian 30 orang. (DepKes RI, 2016)

Jumlah kasus diare dari data per Kabupaten atau Kota Propinsi Sumatera Selatan pada tahun 2017 tertinggi pertama adalah Kota Palembang sebanyak 4559 kasus diare, tertinggi kedua adalah Kabupaten Banyuasin sesbanyak 3058 kasus diare, tertinggi ketiga adalah Kabupaten Muara Enim sebanyak 2579 kasus diare, tertinggi keempat adalah Kabupaten OKI sebanyak 2311 kasus diare, dan tertinggi kelima adalah Kabupaten Musi Rawas sebanyak 1468 kasus diare. (Profil DinKes Provinsi Sum-Sel, 2017).

Jumlah kasus diare dari data Dinas Kesehatan Kota Palembang Tahun 2017 yaitu sebanyak 94.612 penderita dan jumlah diare terendah sebanyak 480 pada tahun 2013. Jumlah kasus diare per Kecamatan di Kota Palembang Tahun 2017 tertinggi pertama adalah Kecamatan Kertapati sebanyak 5213-7404 penderita kasus diare, tertinggi kedua adalah Kecamatan Seberang Ulu I sebanyak 3772-5212 penderita kasus diare, tertinggi ketiga adalah Kecamatan Gandus sebanyak 2290-3771 penderita kasus diare, tertinggi keempat adalah Kecamatan Alang-alang Lebar sebanyak 1308-2289 penderita kasus diare dan tertinggi kelima adalah Kecamatan Plaju sebanyak 1047-1307 penderita kasus diare. (Profil Dinkes Kota Palembang,2017)

Berdasarkan laporan Puskesmas Kenten jumlah balita pada Tahun 2015 sebanyak 1362 balita, dengan penderita diare sebanyak 418 balita. Tahun 2016 sebanyak 1627 balita, dengan penderita diare sebanyak 458 balita. Tahun 2017 jumlah balita sebanyak 1782 balita, dengan penderita diare sebanyak 577 balita. Dari jumlah penderita diare pada balita periode bulan Januari sampai Mei 2018 sebanyak 150 balita.

Sedangkan jumlah keluarga yang menerapkan perilaku hidup bersih dan sehat berdasarkan data dari Dinas Kesehatan Kota Palembang di wilayah Padang Selasa adalah pada tahun 2009 dari 5.925 keluarga yang menerapkan perilaku hidup bersih dan sehat adalah 5.051 ( 85,2\%), tahun 2010 dari jumlah pantau sebanyak 1.656 yang menerapkan perilaku hidup bersih dan sehat adalah sebanyak 1.312 ( 79,53\%), sedangkan pada tahun 2011 dari jumlah pantau sebanyak 4.730 yang menerapkan perilaku hidup bersih dan sehat adalah 3.631 (76,8\%) (Dinkes 2011).

Terkait masih tingginya angka kejadian diare dan risiko kematian yang diakibatkan penyakit diare, maka peneliti tertarik untuk melakukan penelitian mengenai "Faktorfaktor perilaku ibu yang berhubungan dengan kejadian diare pada balita di Wilayah Kerja Puskesmas Kenten Kota Palembang Tahun 2018.

http://jurnalilmiah.stikescitradelima.ac.id/index.php/JI Vol.3,No.1, Juli 2019

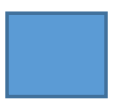




\section{METODE PENELITIAN}

Jenis penelitian yang digunakan adalah deskriptif analitik, yaitu penelitian yang menggali fenomena kesehatan terjadi dengan pendekatan cross sectional dimana variabel independen dan variabel dependen diobservasi sekaligus pada saat yang sama.

Populasi dalam penelitian ini adalah seluruh ibu yang meiliki balita yang terkena diare periode bulan Januari sampai Mei 2018 yang berjumlah 150 orang. Sampel penelitian adalah sebagian dari populasi yang akan diteliti dan dianggap mewakili populasi dengan cara accidental sampling yaitu berdasarkan faktor spontanitas artinya semua ibu yang mempunyai anak balita yang datang karena terkena diare sampai berjumlah 60 orang. Analisis data yang digunakan untuk mencari hubungan dan membuktikan hipotesis antara variabel independen dan variabel dependen, kemudian dievaluasi dengan uji Chi-Square

\section{HASIL DAN PEMBAHASAN}

\subsection{Analisis Univariat}

Tabel 4.1 Distribusi Frekuensi kejadian diare pada balita Tahun 2018

\begin{tabular}{llcc}
\hline $\begin{array}{c}\text { N } \\
\text { o }\end{array}$ & $\begin{array}{c}\text { Kejadian } \\
\text { diare pada } \\
\text { balita }\end{array}$ & Jumlah & Persentase \\
\hline 1 & Diare Berat & 32 & $53,3 \%$ \\
2 & $\begin{array}{l}\text { Diare } \\
\text { Ringan }\end{array}$ & 28 & $46,7 \%$ \\
& Jumlah & 60 & $100 \%$ \\
\hline
\end{tabular}

Berdasarkan tabel 4.1 di atas dapat diketahui balita yang mengalami kejadian diare berat sebanyak 32 orang $(53,3 \%)$ sedangkan balita yang mengalami diare ringan sebanyak 28 orang $(46,7 \%)$.

\section{Tabel 4.2 Distribusi $\quad$ Frekuensi Pemberian ASI pada balita Tahun 2018}

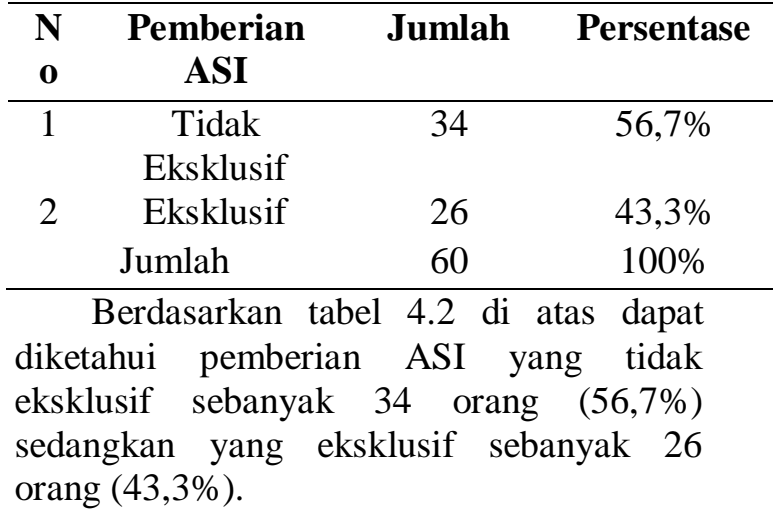

Tabel 4.3 Distribusi Frekuensi penggunaan botol susu Tahun 2018

\begin{tabular}{cccc}
\hline No & $\begin{array}{c}\text { Pengguna } \\
\text { an botol } \\
\text { susu }\end{array}$ & Jumlah & Persentase \\
\hline 1 & $\begin{array}{c}\text { Kurang } \\
\text { baik }\end{array}$ & 35 & $58,3 \%$ \\
2 & Baik & 25 & $41,7 \%$ \\
& Jumlah & 60 & $100 \%$ \\
\hline \multicolumn{3}{c}{ Berdasarkan tabel 4.3 di atas dapat } \\
diketahui penggunaan botol susu yang \\
kurang baik sebanyak 35 orang (58,3\%) \\
sedangkan yang menggunakan botol susu \\
secara baik sebanyak 25 orang (41,7\%).
\end{tabular}

Tabel 4.4 Distribusi Frekuensi kebiasaan mencuci tangan Tahun 2018

\begin{tabular}{clcc}
\hline No & $\begin{array}{c}\text { Kebiasaan } \\
\text { mencuci } \\
\text { tangan }\end{array}$ & Jumlah & Persentase \\
\hline 1 & $\begin{array}{l}\text { Kurang } \\
\text { baik }\end{array}$ & 38 & $63,3 \%$ \\
2 & Baik & 22 & $36,7 \%$ \\
& Jumlah & 60 & $100 \%$ \\
\hline \multicolumn{3}{c}{ Berdasarkan tabel 4.4 di atas dapat } \\
diketahui kebiasaan mencuci tangan yang \\
kurang baik sebanyak 38 orang (63,3\%)
\end{tabular}

http://jurnalilmiah.stikescitradelima.ac.id/index.php/JI Vol.3,No.1, Juli 2019 
sedangkan yang mencuci tangan secara baik sebanyak 22 orang $(36,7 \%)$.

\subsection{Analisis Bivariat}

Tabel 4.5 Hubungan Perilaku ibu dalam pemberian ASI dengan kejadian diare pada balita

\begin{tabular}{|c|c|c|c|c|c|c|c|c|}
\hline \multirow{3}{*}{$\begin{array}{l}\text { Pemb } \\
\text { erian } \\
\text { ASI }\end{array}$} & \multicolumn{4}{|c|}{$\begin{array}{ll}\text { Kejadian diare } \\
\text { pada Balita }\end{array}$} & \multirow{2}{*}{\multicolumn{2}{|c|}{$\begin{array}{l}\text { Juml } \\
\text { ah }\end{array}$}} & \multirow{3}{*}{$\begin{array}{l}\text { P } \\
\text { Val } \\
\text { ue }\end{array}$} & \multirow{3}{*}{$\begin{array}{l}\text { PR } \\
95 \\
\% \\
\text { CI } \\
\end{array}$} \\
\hline & \multicolumn{2}{|c|}{ Berat } & \multicolumn{2}{|c|}{$\begin{array}{l}\text { Ringa } \\
\mathrm{n}\end{array}$} & & & & \\
\hline & $\mathrm{n}$ & $\%$ & $\mathrm{n}$ & $\%$ & $\mathrm{~N}$ & $\%$ & & \\
\hline Tdk & 25 & 73 & 9 & 26 & 3 & 1 & 0,0 & \\
\hline $\begin{array}{l}\text { Ekskl } \\
\text { usif }\end{array}$ & & ,5 & & 5 & 4 & $\begin{array}{l}0 \\
0\end{array}$ & 01 & $\begin{array}{l}31 \\
(5,3\end{array}$ \\
\hline $\begin{array}{l}\text { Ekskl } \\
\text { usif }\end{array}$ & 7 & $\begin{array}{c}26 \\
, 9\end{array}$ & $\begin{array}{l}1 \\
9\end{array}$ & $\begin{array}{l}73, \\
1\end{array}$ & $\begin{array}{l}2 \\
6\end{array}$ & $\begin{array}{l}1 \\
0\end{array}$ & & 09) \\
\hline $\begin{array}{l}\text { Juml } \\
\text { ah }\end{array}$ & 32 & $\begin{array}{l}53 \\
, 3\end{array}$ & $\begin{array}{l}2 \\
8\end{array}$ & $\begin{array}{l}46 \\
7\end{array}$ & $\begin{array}{l}6 \\
0\end{array}$ & $\begin{array}{l}1 \\
0 \\
0\end{array}$ & & \\
\hline
\end{tabular}

Dari tabel 4.5 dapat dilihat bahwa perilaku ibu saat pemberian ASI tdk eksklusif dengan balita yang mengalami kejadian diare berat sebanyak 25 orang $(73,5 \%)$ dan yang mengalami kejadian diare ringan sebanyak 9 orang $(26,5 \%)$. Sedangkan perilaku ibu saat pemberian ASI eksklusif dengan balita yang mengalami diare berat sebanyak 7 orang $(26,9 \%)$ dankejadian diare ringan sebanyak 19 orang $(73,1 \%)$. Hasil uji statistik dengan menggunakan Chi square didapat $\rho$ value $=$ $0,001 \alpha<0,05$. Hipotesa menunjukkan ada hubungan antara pemberian ASI dengan kejadian diare pada balita.

Tabel 4.6 Hubungan Perilaku ibu saat penggunaan botol susu dengan kejadian diare pada balita

\begin{tabular}{|c|c|c|c|c|c|}
\hline $\begin{array}{l}\text { Peng } \\
\text { guna }\end{array}$ & $\begin{array}{l}\text { Kejad } \\
\text { pada } \mathrm{E}\end{array}$ & $\begin{array}{l}\text { diare } \\
\mathrm{a}\end{array}$ & Jumlah & $\begin{array}{l}\mathrm{P} \\
\mathrm{V}\end{array}$ & $\begin{array}{l}\text { PR } \\
95\end{array}$ \\
\hline $\begin{array}{l}\text { an } \\
\text { botol }\end{array}$ & Berat & $\begin{array}{l}\text { Rin } \\
\text { gan }\end{array}$ & & $\begin{array}{l}\text { al } \\
\text { ue }\end{array}$ & $\begin{array}{l}\% \\
\text { CI }\end{array}$ \\
\hline
\end{tabular}

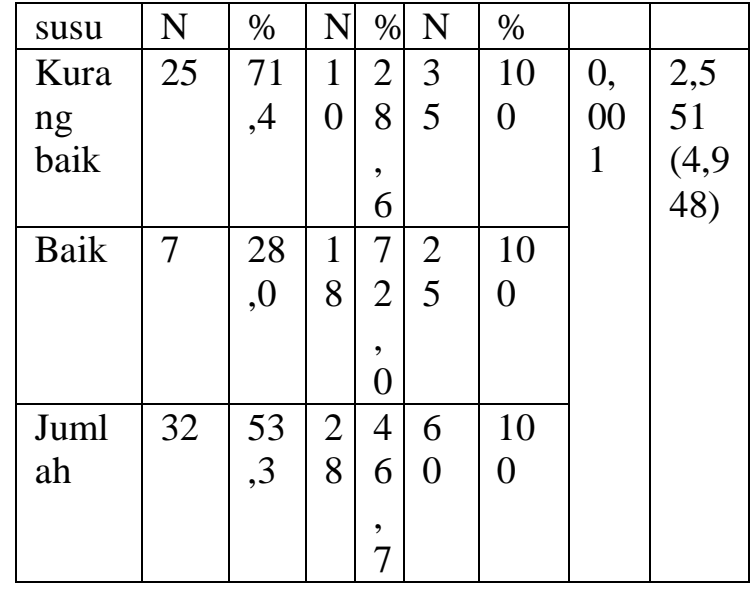

Dari tabel 4.6 dapat dilihat bahwa perilaku ibu saat penggunaan botol susu yang kurang baik dengan balita yang mengalami kejadian diare berat sebanyak 25 orang $(71,4 \%)$ dan yang mengalami kejadian diare ringan sebanyak 10 orang $(28,6 \%)$. Sedangkan perilaku ibu saat pemberian ASI eksklusif dengan balita yang mengalami diare berat sebanyak 7 orang $(28,0 \%)$ dan kejadian diare ringan sebanyak 18 orang $(72,0 \%)$. Hasil uji statistik dengan menggunakan Chi square didapat $\rho$ value $=$ $0,001 \alpha<0,05$. Hipotesa menunjukkan ada hubungan antara penggunaan botol susu dengan kejadian diare pada balita.

Tabel 4.7 Hubungan Perilaku ibu kebiasaan mencuci tangan dengan kejadian diare

\begin{tabular}{|c|c|c|c|c|c|c|c|c|}
\hline \multirow{3}{*}{$\begin{array}{l}\text { Kebi } \\
\text { asaan } \\
\text { menc } \\
\text { uci } \\
\text { tanga } \\
\mathrm{n}\end{array}$} & \multicolumn{4}{|c|}{$\begin{array}{l}\text { Kejadian diare } \\
\text { pada Balita }\end{array}$} & \multirow{2}{*}{\multicolumn{2}{|c|}{$\begin{array}{l}\text { Jumla } \\
\mathrm{h}\end{array}$}} & \multirow{3}{*}{$\begin{array}{l}\mathrm{P} \\
\mathrm{V} \\
\text { al } \\
\text { ue }\end{array}$} & \multirow{3}{*}{$\begin{array}{l}\text { PR } \\
95 \% \\
\text { CI }\end{array}$} \\
\hline & \multicolumn{2}{|c|}{ Berat } & \multicolumn{2}{|c|}{$\begin{array}{l}\text { Ring } \\
\text { an }\end{array}$} & & & & \\
\hline & $\mathrm{n}$ & $\%$ & $\mathrm{~N}$ & $\%$ & $\mathrm{~N}$ & $\%$ & & \\
\hline $\begin{array}{l}\text { Kura } \\
\text { ng } \\
\text { baik }\end{array}$ & 24 & $\begin{array}{l}63 \\
2\end{array}$ & $\begin{array}{l}1 \\
4\end{array}$ & \begin{tabular}{|l|}
3 \\
6, \\
8
\end{tabular} & \begin{tabular}{l|}
3 \\
8
\end{tabular} & $\begin{array}{l}10 \\
0\end{array}$ & $\begin{array}{l}0, \\
06 \\
2\end{array}$ & $\begin{array}{l}1,73 \\
7 \\
(3,17\end{array}$ \\
\hline Baik & 8 & $\begin{array}{l}36 \\
4\end{array}$ & $\begin{array}{l}1 \\
4\end{array}$ & $\begin{array}{l}6 \\
3, \\
6\end{array}$ & $\begin{array}{l}2 \\
2\end{array}$ & $\begin{array}{l}10 \\
0\end{array}$ & & 7) \\
\hline
\end{tabular}




\begin{tabular}{|l|l|l|l|l|l|l|l|l|}
\hline Juml & 32 & 53 & 2 & 4 & 6 & 10 & & \\
ah & &, 3 & 8 & 6, & 0 & 0 & & \\
& & & & 7 & & & & \\
\hline
\end{tabular}

Dari tabel 4.7 dapat dilihat bahwa perilaku ibu dengan kebiasaan mencuci tangan yang kurang baik mengalami kejadian diare berat sebanyak 24 orang $(63,2 \%)$ dan diare ringan sebanyak 14 orang $(36,8 \%)$. Sedangkan perilaku ibu dengan kebiasaan mencuci tangan yang baik mengalami diare berat sebanyak 8 orang $(36,4 \%)$ dan kejadian diare ringan sebanyak 14 orang $(63,6 \%)$. Hasil uji statistik dengan menggunakan Chi square didapat $\rho$ value $=$ $0,001 \alpha<0,05$. Hipotesa menunjukkan ada hubungan antara kebiasaan mencuci tangan dengan kejadian diare pada balita.

\subsection{Hubungan antara perilaku ibu dalam pemberian ASI dengan kejadian diare pada Balita}

Hasil analisis bivariat didapatkan bahwa perilaku ibu dalam pemberian ASI

Tidak eksklusif dengan kejadian diare berat sebesar 73,5\% lebih tinggi dibandingkan dengan pemberian ASI Eksklusif sebesar 26,9\%. Pemberian ASI Eksklusif adalah yang terbaik untuk memberikan nutrisi kepada buah hati, dan merupakan makanan pokok bagi bayi yang sangan dibutuhkan dalam rangka membangun system kekebalan tubuh secara alami agar dapat terhindar dari berbagai penyakit .

Berdasarkan hasil uji statistic yang telah dilakukan dengan menggunakan uji chi -square diperoleh $p$ value $=0,001$ maka dapat disimpulkan bahwa ada hubungan antara pemberian ASI dengan kejadian diare pada balita di Wilayah kerja Puskesmas Kenten Kota Palembang.

\subsection{Hubungan antara perilaku ibu dengan penggunaan botol susu dengan kejadian diare pada Balita}

Hasil analisis bivariat didapatkan bahwa perilaku ibu dengan penggunaan botol susu yang kurang baik dengan kejadian diare berat sebesar 71,4\% lebih tinggi dibandingkan dengan penggunaan botol susu yang baik sebesar 289\%. Penggunaan botol susu yang tidak bersih atau sudah dipakai selama berjam-jam dibiarkan dilingkungan yang panas, sering menyebabkan infeksi usus yang parah karena botol dapat tercemar oleh kuman atau bakteri penyebab diare .

Berdasarkan hasil uji statistic yang telah dilakukan dengan menggunakan uji chi -square diperoleh $p$ value $=0,001$ maka dapat disimpulkan bahwa ada hubungan antara penggunaan botol susu dengan kejadian diare pada balita di Wilayah kerja Puskesmas Kenten Kota Palembang.

4.5 Hubungan antara perilaku ibu dalam kebiasaan mencuci tangan dengan kejadian diare pada Balita

Hasil analisis bivariat didapatkan bahwa perilaku ibu dalam kebiasaan mencuci tangan yang kurang baik dengan kejadian diare berat sebesar $63,2 \%$ lebih tinggi dibandingkan dengan kebiasaan yang baik sebesar 36,4\%. Kebiasaan yang berhubungan dengan kebersihan perorangan yang penting dalam penularan kuman diare adalah mencuci tangan. Mencuci tangan dengan sabun, terutama sesudah buang air besar, sesudah membuang tinja anak, sebelum menyuapi makan anak dan sesudah makan, mempunyai dampak terhadap kejadian diare.

Berdasarkan hasil uji statistic yang telah dilakukan dengan menggunakan uji chi -square diperoleh $p$ value $=0,001$ maka dapat disimpulkan bahwa ada hubungan

http://jurnalilmiah.stikescitradelima.ac.id/index.php/JI Vol.3,No.1, Juli 2019

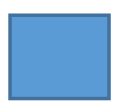


antara kebiasaan mencuci tangan dengan kejadian diare pada balita di Wilayah kerja Puskesmas Kenten Kota Palembang.

\section{SIMPULAN}

Hasil penelitian yang telah dilakukan terhadap 60 orang, sebanyak 32 balita $(53,3 \%)$ yang mengalami diare berat dan 28 balita $(46,7 \%)$ sesbagai berikut :

1. Berdasarkan hasil uji chi-square pada pemberian ASI tidak eksklusif diperoleh $p$-value $=0,001<0,05$ dengan nilai $\mathrm{PR}=2,731$ yang artinya ada hubungan antara pemberian ASI dengan kejadian diare pada balita di Wilayah Kerja Puskesmas Kenten Kota Palembang Tahun 2018.

2. Berdasarkan hasil uji chi-square pada penggunaan botol susu yang kurang baik diperoleh $p$-value $=0,001<0,05$ dengan nilai $P R=2,551$ yang artinya ada hubungan antara penggunaan botol susu dengan kejadian diare pada balita di Wilayah Kerja Puskesmas Kenten Kota Palembang Tahun 2018.

3. Berdasarkan hasil uji chi-square pada pemberian ASI tidak eksklusif diperoleh $p$-value $=0,001<0,05$ dengan nilai $\mathrm{PR}=1,737$ yang artinya ada hubungan antara kebiasaan mencuci tangan dengan kejadian diare pada balita di Wilayah Kerja Puskesmas Kenten Kota Palembang Tahun 2018.

\section{DAFTAR PUSTAKA}

Asmadi dan Suharno, 2012. Dasar-dasar Teknologi Pengolahan Air Limbah. Yogyakarta.

Bagoes Mantra, Ida,2007. Demografi Umum.Yogyakarta, Pustaka Pelajar.

Depkes RI, 2016 Profil Kesehatan Indoensi, Jakarta.
Dinkes Propinsi Sum-Sel Sehat, 2017, Sumatera Selatan Sehat, Proyek Pemberdayaan Masyarakat Bidang Kesehatan, Palembang.

Entjang, Indan, 2000. Ilmu Kesehatan Masyarakat, Penerbit PT.Citra Aditya Bakti.

Hartono, S.P,2014. Analisis Data.Jakarta, Penerbit Pustaka Fakultas Kesehatan Masyarakat UI.

Kemenkes RI, 2011. Panduan Sosialisasi Tatalaksana Diare pada balita. Jakarta.

Putranto, Kusno, 2000. Kesehatan Lingkungan, Jakarta: Universitas Indonesia Fakultas Kesehatan Masyarakat.

Notoatmodjo, S.,2010, Ilmu Perilaku Dalam Kesehatan, Jakarta. PT.Rineka CIpta.

Puskesmas Kenten, 2017. Laporan Tahunan, Puskesmas Kenten Palembang

Sodikin, 2012. Diare Akut pada anak: Gangguan Sistem Gastrointestinal dan Hepatobilier,Jakarta:Salemba Medika.

Soetjingsih, 2003. Tumbuh Kembang Anak, Jakarta. Penerbit Buku Kedokteran EGC.

Widyastuti, 2005. Epidemiologi Suatu Pengantar, Edisi 2, Jakarta:EGC 